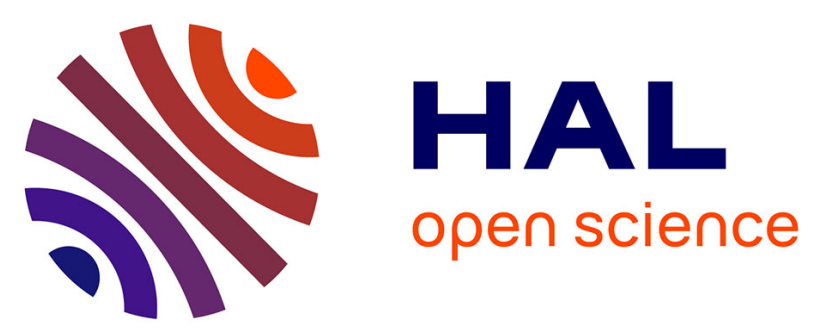

\title{
Relation between DNA double-strand breaks and energy spectra of secondary electrons produced by different $\mathrm{X}$-ray energies
}

Amélie Freneau, Morgane dos Santos, Pascale Voisin, Nicolas Tang, Marta Bueno Vizcarra, Carmen Villagrasa, Laurence Roy, Aurelie Vaurijoux, Gaetan Gruel

\section{To cite this version:}

Amélie Freneau, Morgane dos Santos, Pascale Voisin, Nicolas Tang, Marta Bueno Vizcarra, et al.. Relation between DNA double-strand breaks and energy spectra of secondary electrons produced by different X-ray energies. International Journal of Radiation Biology, 2018, 94 (12), pp.1075-1084. 10.1080/09553002.2018.1518612 . hal-02635749

\section{HAL Id: hal-02635749 \\ https://hal.science/hal-02635749}

Submitted on 27 May 2020

HAL is a multi-disciplinary open access archive for the deposit and dissemination of scientific research documents, whether they are published or not. The documents may come from teaching and research institutions in France or abroad, or from public or private research centers.
L'archive ouverte pluridisciplinaire HAL, est destinée au dépôt et à la diffusion de documents scientifiques de niveau recherche, publiés ou non, émanant des établissements d'enseignement et de recherche français ou étrangers, des laboratoires publics ou privés.

\section{다)(1) $(5$}

Distributed under a Creative Commons Attribution - NonCommerciall 4.0 International 


\section{Relation between DNA double-strand breaks and energy spectra of secondary electrons produced by different $X$-ray energies}

Amelie Freneau $^{\mathrm{a}}$, Morgane Dos Santos ${ }^{\mathrm{a}}$, Pascale Voisin ${ }^{\mathrm{a}}$, Nicolas Tang ${ }^{\mathrm{c}}$, Marta

Bueno Vizcarra ${ }^{c}$, Carmen Villagrasa ${ }^{c}$, Laurence Roy ${ }^{\mathrm{b}}$, Aurelie Vaurijoux ${ }^{\mathrm{a}}$ and Gaetan Gruel $^{\mathrm{a} *}$

anstitute of Radioprotection and Nuclear Safety (IRSN), Department of Research in Radiobiology and Regenerative Medicine, Laboratory of Radiobiology of Accidental Exposition; ${ }^{b}$ Institute of Radioprotection of Nuclear Safety (IRSN), Department of Research on the Biological and Health Effects of Ionizing Radiation, ${ }^{c}$ Institute of Radioprotection and Nuclear Safety, Department of Dosimetry, Laboratory of Ionizing Radiation Dosimetry; BP 17, 92262 Fontenay aux Roses cedex, France.

*corresponding author: gaetan.gruel@irsn.fr 


\title{
Relation between DNA double-strand breaks and energy spectra of secondary electrons produced by different $\mathrm{X}$-ray energies
}

\begin{abstract}
Purpose: In a radiological examination, low-energy $\mathrm{X}$-radiation is used $(<100 \mathrm{keV})$. For other radiological procedures, the energy used is several MeV. ICRP in publication 103 has currently considered that photons irrespective of their energy have the same radiation weighting factor. Nevertheless, there are topological differences at the nanoscale of X-ray energy deposition as a function of its energy spectrum, meaning that the different interactions with living matter could vary in biological efficacy.
\end{abstract}

Materials and Methods: To study these differences, we characterized our irradiation conditions in terms of initial photon energies, but especially in terms of energy spectra of secondary electrons at the cell nucleus level, using Monte Carlo simulations. We evaluated signaling of DNA damage by monitoring a large number of $\gamma \mathrm{H} 2 \mathrm{~A} . \mathrm{X}$ foci after exposure of G0/G1-phase synchronized human primary endothelial cells at a dose from 0.25 to $5 \mathrm{~Gy}$ at $40 \mathrm{kV}, 220 \mathrm{kV}$ and $4 \mathrm{MV}$ X-rays. Number and spatial distribution of $\gamma \mathrm{H} 2 \mathrm{~A}$.X foci were explored. In parallel, we investigated cell behavior through cell death and ability of a mother cell to produce two daughter cells. We also studied the missegregation rate after cell division.

Results: We report a higher number of DNA double-strand breaks signaled by $\gamma \mathrm{H} 2 \mathrm{~A}$.X for 40 $\mathrm{kVp}$ and/or $220 \mathrm{kVp}$ compared to $4 \mathrm{MVp}$ for the highest tested doses of 2 and $5 \mathrm{~Gy}$. We observed no difference between the biological endpoint studies with $40 \mathrm{kVp}$ and $220 \mathrm{kVp} \mathrm{X}$ ray spectra. This lack of difference could be explained by the relative similarity of the calculated energy spectra of secondary electrons at the cell monolayer. .

Conclusion: The energy spectrum of secondary electrons seems to be more closely related to the level of DNA damage measured by $\gamma \mathrm{H} 2 \mathrm{~A}$.X than the initial spectrum of photon energy or voltage settings. Our results indicate that as the energy spectrum of secondary electrons 
increases, the DNA damage signaled by $\gamma \mathrm{H} 2 \mathrm{~A} . \mathrm{X}$ decreases and this effect is observable beyond $220 \mathrm{kVp}$.

Keywords $(3-6)$ : energy X-rays, secondary electrons, DNA damage, $\gamma \mathrm{H} 2 \mathrm{~A} . \mathrm{X}$ foci, cell behavior, missegregation 


\section{Introduction}

X-rays with an energy below $50 \mathrm{keV}$ are frequently applied in diagnostic radiology, particularly mammography. ICRP publication 103 assigned a radiation weighting factor of 1 to this radiation quality(ICRP 2007). This has since been a topic of continuous discussion. One reason for this is a potential risk of radiation-induced cancer by mammography. An increasing amount of in vitro data obtained in the low-energy region indicates a complex dependence of biological effectiveness on photon energy (Lehnert et al. 2008). Indeed, Brenner et al., Goodhead \& Nikjoo et al. and Kellerer et al. have reported an increase in relative biological effectiveness of photons when their energy decreases (Brenner \& Amols 1989; Goodhead \& Nikjoo 1990; Kellerer 2002)

In theory, this difference in biological efficacy could have its origin in the spatial distribution differences at the nanoscale of X-ray energy deposition as a function of their energy spectrum (Goodhead 1988). Indeed, as the photon energy decreases, the nature of its interaction with matter changes. In water, below an energy of $50 \mathrm{keV}$, there is a decrease in the probability of Compton interactions and an increase in photoelectric interactions. This change leads to a modification of the energy spectrum of the secondary electrons created, and thus potentially a change in the quality of the resulting radiation-induced damage, as DNA damage, mis-repair of DNA double-strand breaks and, finally, cell behavior.

Most of the observations reported in the literature concern mis-repair of DNA doublestrand breaks, including those of Mestres et al. who showed an increase in chromosome aberrations in lymphocytes irradiated with $30 \mathrm{kV}, 80 \mathrm{kV}$ and $120 \mathrm{kV}$ X-rays. Slonina et al. showed induction of micronuclei with human fibroblasts and keratinocytes irradiated with $25 \mathrm{kV}$ and Lehnert et al. with human mammary epithelial cells irradiated with $25 \mathrm{kV}$ and $10 \mathrm{kV}$ X-rays (Slonina et al. 2003; Lehnert et al. 2006; Mestres et al. 2008; Lehnert et al. 
2008). In addition, some studies have focused on clonogenic survival, including a study by Panteleeva et al., who showed a decrease in clonogenic survival with primary human epidermal keratinocytes and fibroblasts irradiated with $25 \mathrm{kV}$ compared to $200 \mathrm{kV}$ (Panteleeva et al. 2003). These differences in mis-repair or clonogenic survival rates are likely to originate in the generation of DNA damage.

DNA can be damaged by ionizing radiation in various ways, amongst others by forming double-strand breaks (DSBs). DNA DSBs are probably the most deleterious of the many different types of DNA damage that occur within the eukaryotic cell (Burma et al. 2001). An early response to DSBs is the phosphorylation of a variant form of the histone $\mathrm{H} 2 \mathrm{~A}$ designated H2A.X, located in the area of the break, at serine 139. Phosphorylated H2A.X (called $\gamma \mathrm{H} 2 \mathrm{~A} . \mathrm{X}$ ) can be visualized as foci at break sites by immunofluorescence using phospho-specific antibodies (Paull et al. 2000); these are also known as ionizing radiationinduced foci (IRIF). $\gamma \mathrm{H} 2 \mathrm{~A} . \mathrm{X}$ initiates the formation of a platform to attract and retain proteins, such as Nijmegen breakage syndrome 1 (NBS1), mediator of DNA damage checkpoint protein 1 (MDC1), breast cancer susceptibility 1 (BRCA1), and p53-binding protein 1 (53BP1), and in turn these lead to the recruitment of DNA damage repair proteins (Paull et al. 2000; Kinner et al. 2008; van Attikum \& Gasser 2009; Lisby \& Rothstein 2009). The study of DNA damage formation seems to be a good way to evaluate possible quantitative and qualitative differences in the damage induced by low- and high-energy radiation.

Few studies have focused on characterizing the qualitative differences of DNA damage. Beyreuther et al. (Beyreuther et al. 2009) investigated the number of induced as well as persistent DNA damage foci to investigate late effects after exposure of medical applications such as mammography screening. They studied IRIF formation after exposure to different energy X-rays, $10 \mathrm{kV}, 25 \mathrm{kV}$ and $200 \mathrm{kV}$. They showed energy dependence with 
increasing DNA damage number at decreasing photon energy. Despite highlighting this difference, we currently lack a qualitative analysis of the damage and its effects on cell behavior. Moreover, these comparative studies do not usually explore the biological effects of higher energy X-rays usually used in radiotherapy. This is all the more interesting as it can be assumed that the energy spectrum of the secondary electrons of these latter radiations would be significantly different from the reference X-ray used today in most radiobiology studies (ie. $200-220 \mathrm{kV})$.

In the present work, we deployed a multiparametric experimental strategy allowing us to study different biological endpoints in parallel, from the same pool of cells, ie. cells from one experiment yielding simultaneously foci data, cell division measurements and quantification of chromosome missegregation events. In addition, we characterized our irradiation conditions in terms of initial photon energies, but especially in terms of energy spectra of secondary electrons at the cell nucleus level, using Monte Carlo simulations which took into account their environment at the time of irradiations. Special attention was paid to dosimetry in these experiments to ensure comparable macroscopic absorbed doses among the studied energy spectra, including the exclusive use of plastic dishes for the irradiations (Kegel et al. 2007). Photon spectra from X-ray generators of $40 \mathrm{kVp}, 220 \mathrm{kVp}$ and $4 \mathrm{MVp}$ were used to determine the respective biological effects on human primary cells. We studied the quality of DNA damage through the amount and the spatial distribution in the nucleus of $\gamma \mathrm{H} 2 \mathrm{~A} . \mathrm{X}$ foci in primary endothelial cells with respect to post-irradiation time and X-ray energy. We explored cell behavior to compare the consequences of radiation-induced DNA damage. To explore the regulation of the cell cycle depending on the X-ray energy, the frequencies of cell division and death, and missegregation rate, such as micronuclei and/or nucleoplasmic bridges in mono- and binucleated G1 cells, were analyzed.

\section{Materials and Methods}




\section{Cell Culture}

Primary human umbilical vein endothelial cells (HUVECs) were from the Lonza Group (ref. C2519A, lot0000394986) and isolated by Lonza from human tissue (from 2 females and 2 males) donated after permission was obtained for its use in research applications by informed consent or legal authorization. All cells tested negative for mycoplasma, bacteria, yeast and fungi. Cell lots and donors were tested and negative for HIV-1, hepatitis B and hepatitis C. HUVECs were cultured at $37^{\circ} \mathrm{C}$, with $95 \%$ humidity and $5 \% \mathrm{CO}_{2}$ in $\mathrm{EGM}-2$ media optimized for the proliferation of endothelial cells and supplemented with $5 \%$ fetal bovine serum, hydrocortisone, hFGF-B, VEGF, R3-IGF-1, ascorbic acid, hEGF, gentamicin and amphotericin-B (EGM-2MV BulletKit, CC-3202, Lonza). After thawing, HUVECs were counted using the Cellometer ${ }^{\circledR}$ K2 - Nexcelom, and seeded at 8000 cells $/ \mathrm{cm}^{2}$. Seventy-two hours later, when they are $80 \%$ confluent, the HUVECs were trypsinized and seeded at 8000 cells $/ \mathrm{cm}^{2}$. Ninety-six hours later, on the day of irradiation, G0/G1-phase synchronized HUVECs were obtained by contact inhibition induced in confluent culture. Synchronized cells were seeded $5 \mathrm{~h}$ prior to irradiation at a density of 30000 cells $/ \mathrm{cm}^{2}$ on plastic dishes (1well Permanox $®$ in Nunc $®$ Lab-Tek $®$ chamber slide systems; Thermo Fisher Scientific and Petri; BD Biosciences) and incubated at $37^{\circ} \mathrm{C}$.

\section{Irradiation platform and conditions}

Cell irradiations were performed using two irradiation facilities with different energy ranges: a medical linear accelerator (Elekta Synergy $\left.{ }^{\circledR}\right)$ and a Small Animal Radiation Research Platform (SARRP).

Elekta Synergy ${ }^{\mathbb{B}}$ is a medical linear accelerator and was used to deliver X-rays with a maximal energy of $4 \mathrm{MeV}$ (4 MVp). The dose rate measured with an ionization chamber 
calibrated in air kerma free was about $1 \mathrm{~Gy} \cdot \mathrm{min}^{-1}$ at a distance of $120 \mathrm{~cm}$ from the source and with a $30 \times 30 \mathrm{~cm}$ irradiation field (Table 1)

The SARRP (XSTRAHL, Ltd., UK) is an image-guided micro irradiator, composed of a Varian X-ray tube mounted on a gantry, mainly dedicated to small animal irradiation (Wong et al., 2008). However, thanks to an adequate dosimetry protocol and irradiation configuration set-up (Dos Santos et al. 2018), it is also possible to perform cell irradiation. In this work, two configurations, using two different high voltages, were used with this platform. In both cases, inherent and additional filtrations of 0.8 and $1 \mathrm{~mm}$ of beryllium and aluminum, respectively, a source sample distance of $30.5 \mathrm{~cm}$ and a collimator leading to an $8 \times 8 \mathrm{~cm}$ irradiation field were used (Table 1). The SARRP was used to deliver X-rays with a maximal energy of $40 \mathrm{keV}(40 \mathrm{kVp})$ and $220 \mathrm{keV}(220 \mathrm{kVp})$ at a dose rate of about $1 \mathrm{~Gy}^{\mathrm{min}}{ }^{-1}$ in air kerma, in both cases. The details of the dosimetry protocol used for cell irradiation on the SARRP facility are given in Dos Santos et al, 2018, (Dos Santos et al. 2018). Briefly, absolute dosimetry measurements were performed inside a cell container with an ionization chamber calibrated in air kerma free-in-air and then converted into water kerma free-in-air. Then, attenuation due to the cell culture medium was evaluated using measurements with EBT3 films

For all irradiations configurations, the doses delivered to the cell monolayer were 0.25 , $0.5,1$ and 2 Gy for the earlier time ( $30 \mathrm{~min}$ post-irradiation), and $5 \mathrm{~Gy}$ for the later time ( $5 \mathrm{~h}$ post-irradiation). Culture media were not renewed after irradiation.

The uncertainty in the dose rate measurement was about $5 \%, 3 \%$ and $7 \%$ for $40 \mathrm{kVp}$, $220 \mathrm{kVp}$ and $4 \mathrm{MVp}$ respectively at $\mathrm{k}=2$.

\section{Immunostaining}


HUVECs were immunostained after exposure to X-rays. Briefly, cells were washed with $1 \mathrm{X}$ PBS (14190-094, Life Technologies), fixed with formalin solution 10\% neutral buffered (HT5011, Sigma-Aldrich) and permeabilized with 0.5\% Triton X-100 (T8787, SigmaAldrich) for $3 \mathrm{~min}$, and then washed 1 more time with PBS. The following primary antibodies were used in this study: mouse IgG1 monoclonal anti-phospho-histone H2AX (Ser139) antibody (1:1000; 05-636, clone JBW301, Millipore). Antibodies were diluted in 1X PBS with $2 \%(w / v)$ BSA (bovine serum albumin; A9418, Sigma-Aldrich) and incubated with cells for $1 \mathrm{~h}$ at room temperature (RT). Cells were then washed 3 more times and incubated for $1 \mathrm{~h}$ with a secondary antibody, goat anti-mouse $\operatorname{IgG} 1(\gamma 1)$ coupled to Alexa Fluor $(488$ (2 mg.mL $\mathrm{m}^{-1}, 1: 1000 ;$ A21121, Life Technologies). They were diluted in PBS with $2 \%$ BSA and incubated with cells for $1 \mathrm{~h}$ at RT. Cells were washed as described above. DNA was stained with DAPI (0.2 $\mu$ g.ml-1; 1050A, Euromedex) and mounted with ProLong® Antifade Reagents (P36930, Life Technologies).

\section{Fluorescence image acquisition and analysis}

Image acquisition and analysis were performed with the $\mathrm{Scan}^{\wedge} \mathrm{R}$ platform (Olympus), as described previously (Gruel et al. 2016; Vaurijoux et al. 2017). Briefly, images were acquired on an inverted Olympus IX81 fluorescence microscope with a UPLSAPO 100XO oil immersion objective (Olympus) and an NA of 1.4; the microscope was coupled with an Orca $\mathrm{R}^{2}$ CCD camera (Hamamatsu) and a motorized SCAN IM IX2 stage (Märzhäuser). Image analysis was performed with $\mathrm{Scan}^{\wedge} \mathrm{R}$ analysis software (Olympus). For each channel, images were acquired as $3 \mathrm{z}$-stack images around and including the focus plane with step size of 0.5 $\mu \mathrm{m}$ between planes. The images of the $3 \mathrm{D}$ stack were projected to $2 \mathrm{D}$ xy images using maximum intensity projection. An edge segmentation algorithm was used to detect nuclei in the DAPI channel (main object) and $\gamma \mathrm{H} 2 \mathrm{AX}$ foci in the Alexa Fluor ${ }^{\circledR} 488$ channel (subobject 1). Cells in G0/G1 phase were selected with a "flow cytometry-like" analysis (Gruel et 
al. 2016). A first selection based on the area and circularity of the nuclei was based on the definition of an adequate region on the corresponding scatter plot. This step allowed us to consider a region with only isolated nuclei, by removing from the analysis objects corresponding to nucleus clusters. A second region, based on the integrated intensity levels of DAPI fluorescence associated with the nuclei and Alexa Fluor ${ }^{\circledR} 488$ fluorescence associated with $\gamma \mathrm{H} 2 \mathrm{~A}$.X foci, was measured for each nucleus and was then used to isolate nuclei in G0/G1 phase. IRIF were analyzed only in nuclei within the gate formed by the intersection of these two regions (Vaurijoux et al. 2017).

\section{Analysis of missegregation events}

Forty-eight hours after irradiation, cells were fixed with formalin solution $10 \%$ neutral buffered (HT5011, Sigma-Aldrich), stained with DAPI. (0.2 $\mu \mathrm{g} \cdot \mathrm{ml}-1 ; 1050 \mathrm{~A}$, Euromedex) and mounted with ProLong® Antifade Reagents (P36930, Life Technologies). Micronuclei and/or nucleoplasmic bridges were scored in mono- and binucleated G1 cells.

\section{Videomicroscopy}

Following irradiation, HUVECs, seeded in Corning ${ }^{\mathrm{TM}}$ Falcon ${ }^{\mathrm{TM}}$ Easy-Grip Tissue Culture Dishes, were placed in the incubation system, allowing control of temperature, humidity and $\mathrm{CO}_{2}$ levels, which is mounted on an inverted Olympus IX83 phase microscope with a UPLFLN 10XPH objective (Olympus). The acquisition was performed with $\mathrm{Scan}^{\wedge} \mathrm{R}$ software (Olympus). Six different fields were acquired per dish, every 5 minutes, for 96 hours. Image analysis was performed with Image J, using MTrackJ and Grid Overlay plug ins, allowing us to count the cells able to form 2 daughter cells and the dying cells. When an adherent cell produced two daughter cells, we counted this as one a "cell division" event, and when we observed the disruption of an adherent cell, it was counted as a cell death event. The frequency of division was the number of "cell division" events observed for a given time step, 
divided by the initial number of cells in the live-cell imaging field (the same analysis methodology was used for "cell death" event).

\section{Monte Carlo simulations}

Monte Carlo simulations of the secondary electron spectra were performed using the Geant4 Monte Carlo toolkit version 10.3. To this end, the modeling of the irradiation configurations was performed taking into account the initial photon spectra and the different layers of material between the source and the cells.

In particular, for the SARRP configurations, the initial photon spectra were calculated using Speckcalc software (Poludniowski et al. 2009), whereas for the 4 MV irradiation performed with the medical linear accelerator, the initial photon spectra were derived from figure 10 in Sheikh-Bagheri et al., 2002 (Sheikh-Bagheri \& Rogers 2002). In both cases, the irradiated cells were modeled as a mono-volume of liquid water $5 \mu \mathrm{m}$ in height and $125 \times 85$ $\mathrm{mm}$ in the $\mathrm{x}-\mathrm{y}$ plane in order to ensure electronic equilibrium. Between the photon source and the cell volume (or behind the cell volume), different material layers were taken into account as shown in figure 1.

For the SAARP configurations, the photon source traverses the cell medium, approximated here by a liquid water layer $3 \mathrm{~mm}$ in height, then the cell volume is positioned and a polystyrene layer of $3 \mathrm{~mm}$ is modeled behind to represent the dish material where cells are grown.

In the medical accelerator simulation, a carbon table is located between the beam and the dish containing the cells. Therefore, in the simulation, the first layer traversed by the photon source is a $50 \mathrm{~mm}$ height table ( $2 \mathrm{~mm}$ of carbon fiber $+46 \mathrm{~mm}$ of foam $+2 \mathrm{~mm}$ of carbon fiber), followed by $5 \mathrm{~mm}$ of Plexiglas, then $3 \mathrm{~mm}$ of polystyrene and then the cell 
volume $5 \mu \mathrm{m}$ in height. Behind the cell volume, a $3 \mathrm{~mm}$ liquid water volume representing the cell medium is also taken into account.

The secondary electron spectra at cell level were calculated from the phase space of the electrons entering (or produced) in the modeled cell volume. In order to obtain the phase space of the secondary electrons, photon transport in the different layers of matter was performed using the Livermore physics list (LowEnergy, option 4) in Geant4, which simulates photon interactions to a minimal energy of $250 \mathrm{eV}$. Secondary electrons produced by photons were also transported in the simulated geometry using the physical models available in this physics list. When an electron entered in the cell volume, its kinetic energy, position $(x, y, z)$ and momentum $\left(p_{x}, p_{y}, p_{z}\right)$ were recorded and the electrons were killed, in order to save calculation time. In rare cases, electrons were produced directly by a photon reaction in the cell volume. In this case, the same information was registered in the phase space. This information allowed us to calculate the energy spectra presented in this work and to perform a more detailed simulation of the energy deposition in the cell volume using the information described above as the irradiation source (simulations in progress).

\section{Statistics}

Student's t test was performed to evaluate the statistical significance of any differences among measurements.

\section{Results}

\section{Photon and electron energy spectrum}

Figure 2 reports the photon energy spectrum for irradiations performed on the SARRP Platform at 40 and $220 \mathrm{kVp}$ obtained with the Speckcalc software (Poludniowski et al. 2009). As mentioned before, an additional filtration of $1 \mathrm{~mm}$ of aluminum was used for irradiation. It 
allows lower energy X-rays compared to the reference filtration of $0.15 \mathrm{~mm}$ of copper normally used for irradiation with the SARRP. The $40 \mathrm{kVp}$ voltage was chosen because it is the lower voltage that can be achieved on the SARRP irradiator and is close to the photon energy spectrum used for mammography examinations. This configuration allows a large proportion of very low-energy X-rays leading to photoelectric interactions. The $220 \mathrm{kVp}$ voltage was chosen because it is often considered as a reference voltage for the SARRP and also in the literature. For the $4 \mathrm{MVp}$ irradiation performed with the medical linear accelerator, the initial photon spectra were derived from figure 10 in Sheikh-Bagheri et al., 2002 (SheikhBagheri \& Rogers 2002).

To overcome problems due to the modification of the energy spectrum of the emitted photons, all irradiations were performed without a lid. The mean photon energies were $25.6 \mathrm{keV}, 70.2 \mathrm{keV}$ and around $1.3 \mathrm{MeV}$, respectively, for $40 \mathrm{kVp}, 220 \mathrm{kVp}$ and $4 \mathrm{MVp}$.

Figure 3 reports the secondary electron energy spectrum obtained for the three configurations. The mean energy of the produced secondary electrons increased with X-ray energy, as expected, respectively $14 \mathrm{keV}, 20 \mathrm{keV}$ and $859 \mathrm{keV}$ for $40 \mathrm{kVp}$, and $220 \mathrm{kVp}$ and $4 \mathrm{MVp}$.

\section{Quantification of $\gamma H 2 A . X$ foci per nucleus}

We investigated the number of $\gamma \mathrm{H} 2 \mathrm{~A} . \mathrm{X}$ foci induced by $\mathrm{X}$-rays of different energy spectra. To harmonize the DNA content of the cells at the time of irradiation, we performed our analysis on cells in the same cell cycle state. Thus, we exposed HUVECs synchronized in the $\mathrm{G} 0 / \mathrm{G} 1$ phase of the cell cycle to $0.25,0.5,1$ or $2 \mathrm{~Gy}$ of $40 \mathrm{kVp}, 220 \mathrm{kVp}$ or $4 \mathrm{MVp} \mathrm{X}$-rays and studied $\gamma \mathrm{H} 2 \mathrm{~A} . \mathrm{X}$ foci formation $30 \mathrm{~min}$ after exposure. All irradiations were performed exclusively on adherent cells in plastic dishes. Using automated detection of nuclei and foci, we analyzed a mean of 4200 cells for each replicate experiment so that we could screen 
subpopulations of cells or foci by different characteristics, such as shape, foci spatial distribution in the nuclei, and weight their representativeness within the entire population of exposed cells. All results presented here concern only cells in the G0/G1 phase of the cell cycle.

Thirty minutes post-irradiation, when analyzing dose-by-dose after exposure, we observed no significant difference from 0.25 to $1 \mathrm{~Gy}$ in the mean number of $\gamma \mathrm{H} 2 \mathrm{~A}$.X foci per nucleus among the 3 tested X-ray energies (table 2) (t-test, $p>0.05$ ). However, at 2 Gy, a significant difference between $40 \mathrm{kVp}$ and $4 \mathrm{MVp}$ was measured with, on average, $30.3 \pm$ $2.21,30.6 \pm 2.96$ and $26.4 \pm 0.87 \gamma \mathrm{H} 2 \mathrm{~A} . \mathrm{X}$ foci per nucleus, at $40 \mathrm{kVp}, 220 \mathrm{kVp}$ and $4 \mathrm{MVp}$ respectively (figure 4 ) (mean $\pm \mathrm{SE}$, from at least 3 replicate experiments, t-test, $p=0.03$ ).

In order to study the differences of resolution rate, we studied the IRIF number $5 \mathrm{~h}$ after exposure to $5 \mathrm{~Gy}$, using the same three different qualities of radiation (figure 5). We analyzed a mean of 4500 cells for each condition and performed at least 3 replicate experiments. All results here relate only to cells in the $\mathrm{G} 0 / \mathrm{G} 1$ phase of the cell cycle. We observed, on average, $15.2 \pm 0.80,14.3 \pm 0.67$ and $12.2 \pm 0.54 \gamma \mathrm{H} 2 \mathrm{~A} . \mathrm{X}$ foci per nucleus, respectively (mean \pm SE, from at least 3 replicate experiments). Significant differences were seen between $40 \mathrm{kVp}$ and $4 \mathrm{MVp}$ (t-test, $p=0.008$ ) and between $220 \mathrm{kVp}$ and $4 \mathrm{MVp}$ voltages (t-test, $p=0.01)$

\section{Spatial distribution of $\gamma H 2 A . X$ foci per nucleus}

To investigate if this decrease in mean values could be due to differences in the spatial distribution of $\gamma \mathrm{H} 2 \mathrm{~A} . \mathrm{X}$ foci, we analyzed the mean distance from the nearest neighbor of $\gamma \mathrm{H} 2 \mathrm{~A}$.X foci as a function of their number per nuclei (figures 6 ), $30 \mathrm{~min}$ post-exposure at $0.25,0.5,1$ and $2 \mathrm{~Gy}$, and $5 \mathrm{~h}$ post-exposure at $5 \mathrm{~Gy}$, among the 3 tested X-ray energies. As expected, the distances from the nearest neighbor were dependent on the number of $\gamma \mathrm{H} 2 \mathrm{~A} . \mathrm{X}$ 
foci per nuclei, ie, the more $\gamma \mathrm{H} 2 \mathrm{~A} . \mathrm{X}$ foci, the lower the distance from the nearest neighbor will be. The mean distance was obtained by using the $\mathrm{x}, \mathrm{y}$ coordinates of all $\gamma \mathrm{H} 2 \mathrm{~A}$.X foci, keeping the minimum distance of each $\gamma \mathrm{H} 2 \mathrm{~A} . \mathrm{X}$ focus from each other and calculating the average of all the minimum distances per nucleus. For all doses, $30 \mathrm{~min}$ and $5 \mathrm{~h}$ postirradiation, there was no significant difference between the three qualities of radiation ( $\mathrm{t}$-test, $p>0.05)$.

\section{Cell division and mortality rate as a function of the energy spectra of irradiation}

We also investigated if this difference in the mean number of foci had an impact on cell behavior like cell division and mortality rates. We focused on the two most different energy spectra: $40 \mathrm{kVp}$ and $4 \mathrm{MVp}$. To identify cells able to complete a full cell cycle after exposure, we used phase contrast live-cell imaging of synchronized cells exposed to $5 \mathrm{~Gy}$. All results reported here are from 4 replicate experiments per condition. Around 1500 and 500 events per condition (division + death) were counted for the non-irradiated and irradiated cells, respectively.

Figure 7 shows the cumulated number of cell division events per step of 6 hours, for the non-irradiated and 5 Gy irradiated cells. For the control irradiation, we observed that division events began $18 \mathrm{~h}$ post-plating, and seemed to be delayed by around $6 \mathrm{~h}$ for the exposure conditions. For the $5 \mathrm{~Gy}$ irradiated cells, more than a third of the initial cells achieved one cell division within $42 \mathrm{~h}$ following exposure. No significant difference was found between the two qualities of radiation studied, with $34.2 \pm 24.2 \%$ and $40.9 \pm 7.7 \%$ of division frequency $42 \mathrm{~h}$ post-exposure after $5 \mathrm{~Gy}$ of irradiation at $40 \mathrm{kVp}$ and $4 \mathrm{MVp}$, respectively (mean $\pm \mathrm{SE}$, t-test, $p>0.05$ ).

Figure 8 shows the division frequency during 6-h periods over 96 hours after exposure. The post-irradiation cell cycle recovery was the same for the two ionizing radiation 
qualities. The cell division activity peaked between 24 and $30 \mathrm{~h}$ post-irradiation and stopped $60 \mathrm{~h}$ after exposure. No significant difference was observed between $40 \mathrm{kVp}$ and $4 \mathrm{MVp}$ (ttest, $p>0.05)$.

Figure 9 shows the frequency of mortality for the 5 Gy irradiated cells at $40 \mathrm{kVp}$ and $4 \mathrm{MVp}$. We observed that the mortality frequency started to increase between 24 and $30 \mathrm{~h}$ post-irradiation for both energies, with $0.6 \pm 0.58 \%$, and $0.6 \pm 0.61 \%$ of cells that had died, at $40 \mathrm{kVp}$ and $4 \mathrm{MVp}$, respectively. We observed a maximum in the relative frequency of mortality between 54 and $60 \mathrm{~h}$ post-irradiation, with a mortality frequency of $4.1 \pm 1.92 \%$, and $5.3 \pm 0.78 \%$, respectively, at $40 \mathrm{kVp}$ and $4 \mathrm{MVp}$. There was no significant difference between the two radiation qualities (mean $\pm \mathrm{SE}$, t-test, $p>0.05$ ). Also, we found no difference with our experimental protocol in terms of radiation-induced cell death.

\section{Missegregation events following exposure at two radiation qualities after cell division}

The synchronization of cells at the time of exposure and their ability to divide in the same proportions for both qualities of radiation allowed the comparative measurement of missegregation events observed $48 \mathrm{~h}$ post-irradiation. These missegregation events gave us an indication of the rate of abnormal chromosomal structures formed in each of the studied irradiation conditions. This analysis was performed on the same slides as those used for the $\gamma \mathrm{H} 2 \mathrm{~A}$.X foci scoring and allowed continuity to be maintained between different biological measurements. Around 4100 micronuclei and/or nucleoplasmic bridges in mono- and binucleated G1 cells were scored per condition. Among the entire population of G1 cells, the frequency of micronuclei and/or nucleoplasmic bridges in mono- and binucleated cells was not significantly different between $40 \mathrm{kVp}$ and $4 \mathrm{MVp}$ (t-test, $\mathrm{p}>0.05$ ), with $8.68 \pm 3.82 \%$ and $11.78 \pm 4.40 \%$ of missegregation events (mean $\pm \mathrm{SE}$ from at least 3 replicate experiments), respectively (table 3 ). 


\section{Discussion}

The question of the biological effectiveness of X-rays as a function of their energy spectra was raised several decades ago (Brenner \& Amols 1989; Kellerer 2002; Lehnert et al. 2006; Lehnert et al. 2008), but is hard to solve definitively. The main reason is that the development of irradiation configurations suitable for a biological comparison is complicated by the combination of strong dosimetric constraints related to low-energy X-rays (Kegel et al. 2007) and the need to carry out biological experiments under relevant and robust conditions. The goal is to evaluate a possible difference in effects on a biological target by ensuring that the absorbed dose at this target is equal. In other words, it is a matter of verifying whether the micro- and nanodosimetric differences between low- and high-energy X-rays are sufficient, by themselves, to lead to different biological consequences. In this complex comparison, the role of the nano- and micro-organization of the biological target of interest such as local or temporal variations in DNA density (chromatin organization and cell cycle, respectively) should not be forgotten. We sought to take into account these considerations in the experimental development of irradiation and the interpretation of our results. We also maximized the robustness of our biological quantifications by analyzing several thousand cells for each experimental condition and replicate experiments.

In the present work, we observed no difference between the biological endpoint studies with $40 \mathrm{kVp}$ and $220 \mathrm{kVp} \mathrm{X-ray} \mathrm{spectra.} \mathrm{This} \mathrm{lack} \mathrm{of} \mathrm{difference} \mathrm{could} \mathrm{be} \mathrm{explained} \mathrm{by}$ the relative similarity of the calculated energy spectra of secondary electrons at the cell monolayer. Indeed, the mean energies of the 2 spectra of secondary electrons were $14 \mathrm{keV}$ and $20 \mathrm{keV}$ and the shape of these spectra is also quite similar. This emphasizes the difficulty of interpreting biological results only on the basis of X-ray irradiation voltage settings or initial photon energies. In our experimental settings, despite a significant difference in energy spectra of photons between $40 \mathrm{kVp}$ and $220 \mathrm{kVp}$ (mean energy of photons at $40 \mathrm{kVp}=25.6$ 
$\mathrm{keV}$; mean energy of photons at $220 \mathrm{kVp}=70.2 \mathrm{keV}$; figure 2), the calculated energy spectra of secondary electrons at the cell level were close (mean energy of secondary electrons at 40 $\mathrm{kVp}=14 \mathrm{keV}$; mean energy of secondary electrons at $220 \mathrm{kVp}=20 \mathrm{keV}$; figure 3).

Nevertheless, we report a higher number of DNA double-strand breaks signaled by $\gamma \mathrm{H} 2 \mathrm{~A}$.X for $40 \mathrm{kVp}$ and/or $220 \mathrm{kVp}$ compared to $4 \mathrm{MVp}$ for the highest tested doses of 2 and 5 Gy. Our results seems to indicate that as the energy spectrum of secondary electrons increases, the DNA damage signaled by $\gamma \mathrm{H} 2 \mathrm{~A} . \mathrm{X}$ decreases and this effect is observable beyond $220 \mathrm{kVp}$. In other words, the increase in the number of $\gamma \mathrm{H} 2 \mathrm{~A} . \mathrm{X}$ already reported by Beyreuther et al. for low-energy X-rays (Beyreuther et al. 2009) could still be measured in our case by taking a reference radiation of $4 \mathrm{MVp}$. In fact, Beyreuther et al. studied energy spectra below $40 \mathrm{kVp}$ and reported an increase of the number of $\gamma \mathrm{H} 2 \mathrm{~A} . \mathrm{X}$ and 53BP1 colocated foci for $10 \mathrm{kVp}$ and $25 \mathrm{kVp}$ compared to $200 \mathrm{kVp}, 2 \mathrm{~h}$ post-irradiation, at $0.5,1,2,4$ and 6 Gy (Beyreuther et al. 2009). In their experimental conditions, the reported mean energy of secondary electrons at the cell monolayer was significantly lower for the 2 tested lowenergy X-ray conditions ( $3.7 \mathrm{keV}$ and $7 \mathrm{keV}$ for $10 \mathrm{kVp}$ and $25 \mathrm{kVp}$, respectively) compared to their reference X-ray voltage of $200 \mathrm{kVp}(21.4 \mathrm{keV}$ as mean energy of secondary electrons). This confirms that the analysis of the relation between the mean number of foci and the energy of the X-rays must be made in terms of the energy of secondary electrons at the cell level and not directly on the photon spectra. This is something to keep in mind as the energy of the secondary electrons interacting with cells can be strongly influenced by the experimental set-up.

Furthermore, this effect seems also to be related to the absorbed dose. In our work, the differences between $40 / 220 \mathrm{kVp}$ and $4 \mathrm{MVp}$ exposures were observed only for absorbed doses higher than or equal to $2 \mathrm{~Gy}$. Beyreuther et al. reported the same kind of effect. They did not observe a significant difference $24 \mathrm{~h}$ after exposure for doses up to $2 \mathrm{~Gy}$, but they 
reported an elevated yield for higher doses, (ie, $4 \mathrm{~Gy}$ and more) between 10/25 kVp and $200 \mathrm{kV}$. Thus, to observe a differential effect between the radiation qualities, doses above a specific threshold had to be used. This might suggest a joint role of the absorbed doses and secondary electron energy spectra in the ability to observe biological difference in terms of DNA damage signaled by $\gamma \mathrm{H} 2 \mathrm{~A}$.X. This could be consistent with a specific nanodosimetric explanation of these differences. This still needs to be identified, and this hypothesis is currently being explored in our laboratory.

However, there are also several methodological differences between the work of Beyreuther et al. and ours that could partly explain the differences in reported results. One of them is that we chose to work on synchronized cells in the G0/G1 phase of the cell cycle at the time of irradiation. We made this choice to generate damage in cells that are mostly in the same state of the cell cycle, with the same amount and spatial distribution of DNA. The other advantage of this choice concerns the study of late DNA damage signaling. There are different repair pathways with their own repair kinetics and risk of failure. Some depend on the state of the cell cycle in which the damage occurs. Thus the rate of persistent damage can be strongly correlated with the distribution of cells in the cell cycle at the time of irradiation. In the work by Beyreuther et al., we can assume that their cells, at the time of irradiation, were not synchronized. They do not specify their distribution among the different cell cycle phases, nor the phase of the cell cycle of the cells in which they scored DNA damage signaling. It would be particularly interesting to investigate if these experimental differences contribute to the results.

Independently of the measurements of DNA damage signaling, two groups have reported differences in the number of chromosome aberrations in lymphocytes for different $\mathrm{X}$-ray energy spectra. Mestres et al. showed that exposure to $30 \mathrm{kVp}$ X-rays resulted in a slight increase in the $\alpha$ coefficient of dose-effect curves compared to 80 and $120 \mathrm{kVp} \mathrm{X}$ rays 
(Mestres et al. 2011). They also reported that $30 \mathrm{kVp} \mathrm{X}$ rays were more efficient in inducing complex aberrations than $120 \mathrm{kVp}$. Schmid et al. observed an increase of the frequency of dicentrics per cell after irradiation at $10 \mathrm{kV}$ compared to $60 \mathrm{kV}$ (Schmid et al. 2002). Once again, these increases in the rate of mostly unstable chromosome aberrations were reported for X-ray irradiation below $40 \mathrm{kVp}$. It would have been interesting to know the energy spectrum of secondary electrons corresponding to their experimental conditions. However, with our experimental set-up, no difference in the rate of missegregation was measured between $40 \mathrm{kVp}$ and $4 \mathrm{MVp}$. Thus, the extra $15 \%$ of $\gamma \mathrm{H} 2 \mathrm{~A}$.X foci observed 30 min after $2 \mathrm{~Gy}$ of $40 \mathrm{kVp} \mathrm{X}$-rays may not be sufficient to generate a detectable increase of the frequency of unstable chromosome aberrations leading to missegregation events. However, one should keep in mind that the geometry and size of lymphocytes are significantly different from those of the HUVECs used in the present study. The nuclei of HUVECs have a volume two times larger than lymphocyte nuclei, which implies a mean density of DNA twice that in the latter. So the impact on DNA damage of the spatial distribution of energy deposits for a given photon energy spectra may not be the same in lymphocytes and in endothelial cells. In addition to the difference of size, the shape of adherent cells like HUVEC compared to lymphocytes may also be involved in the probability of formation of chromosome aberrations. The involvement of these geometric parameters in differential effects of X-rays as a function of their energy is currently under investigation.

In conclusion, the results presented here indicate that the energy spectrum of secondary electrons seems to be more closely related to the level of DNA damage measured by $\gamma \mathrm{H} 2 \mathrm{~A} . \mathrm{X}$ than the initial spectrum of photon energy or voltage settings. They confirm the potential joint role of the absorbed doses and secondary electron energy spectra in the ability to observed biological difference in terms of DNA damage signaled by $\gamma \mathrm{H} 2 \mathrm{~A}$.X. This highlights the importance of identifying and characterizing specific nanodosimetric 
explanations of these differences. However, from a radiation protection point of view, it is important to note that differences in the level of DNA damage observed at doses of 2 Gy and over could not be associated with differential effects on downstream biological endpoints in the range of tested energies under our experimental conditions.

\section{Acknowledgments}

The authors would like to thank $\mathrm{Y}$. Ristic for performing the radiation exposure with the Elekta Synergy accelerator.

\section{Declaration of interest}

The authors report no conflict of interest. The authors alone are responsible for the content and writing of the paper. 
Figures:

Figure 1: Modeling of irradiation configurations for the medical linear accelerator (panel A) and the SARRP configuration (panel B) used for the Monte Carlo simulations.

Figure 2: X-ray photon energy spectra obtained at $40 \mathrm{kVp}$ (blue line) and $220 \mathrm{kVp}$ (purple line) using SpekCalc software. Their mean energies are $25.6 \mathrm{keV}$ and $70.2 \mathrm{keV}$, respectively.

Figure 3: Secondary electron energy spectra at the cell volume level, obtained by Monte Carlo simulations using Geant4 on the SARRP at $40 \mathrm{kVp}$ (blue line) and $220 \mathrm{kVp}$ (purple line) and on the linear accelerator at $4 \mathrm{MVp}$ (black line). Their mean energies are $14 \mathrm{keV}, 20 \mathrm{keV}$ and $859 \mathrm{keV}$, respectively.

Figure 4: Dose-effect curves derived from the average number of $\gamma$-H2A.X IRIF per nucleus measured in G0/G1 primary HUVECs as a function of X-ray energy, 30 min after irradiation. The measured values are given for $40 \mathrm{kVp}$ (blue open circles), $220 \mathrm{kVp}$ (violet open diamonds) and $4 \mathrm{MVp}$ (black open triangles) X-rays. Mean numbers $\gamma$-H2A.X IRIF per nucleus were evaluated with image analysis software on around 4200 cells for each dose, and obtained from at least 3 experiments. Significance was tested using Student's t test.

Figure 5: Average number of $\gamma \mathrm{H} 2 \mathrm{~A} . \mathrm{X}$ foci in $\mathrm{G} 0 / \mathrm{G} 1$ primary HUVECs $( \pm$ S.E.) after irradiation by 5 Gy as a function of X-ray energy (blue open circles, violet diamonds and black triangles, respectively $40 \mathrm{kVp}, 220 \mathrm{kVp}$ and $4 \mathrm{MVp}) 5 \mathrm{~h}$ after irradiation. The measured values were evaluated with image analysis software on around 4500 cells for each X-ray energy, corresponding to 3 or 4 experiments.

Figures 6: Distance from the nearest neighbor as a function of the number of $\gamma \mathrm{H} 2 \mathrm{~A}$.X foci per nucleus and the percentage of the number of nuclei and the X-ray energy after irradiation by $0.25,0.5,1$ and $2 \mathrm{~Gy}, 30$ min post-irradiation (panels A, B, C and D, respectively) and 5 Gy, 
$5 \mathrm{~h}$ post-irradiation (panel E). The measured values ( \pm S.E.) are given for $40 \mathrm{kVp}$ (blue open circles), $220 \mathrm{kVp}$ (violet open diamonds) and $4 \mathrm{MVp}$ (black open triangles) X-rays. Percentages of the number of nuclei were calculated in around $4400 \mathrm{G} 0 / \mathrm{G} 1$ cells exposed to $40 \mathrm{kVp}$ (blue bar), $220 \mathrm{kVp}$ (violet bar) and $4 \mathrm{MVp}$ (grey bar) X-rays. Values were obtained from at least 3 experiments. Significance was tested using Student's $t$ test.

Figure 7: Cumulated number of cell division events ( \pm S.E.) for non-irradiated cells and for cells after 5 Gy irradiation. The results shown were obtained by averaging the data of 8 experiments, for the control condition (green curve), and 4 experiments for the irradiated conditions at $40 \mathrm{kVp}$ and $4 \mathrm{MVp}$ (blue and black curves, respectively), and correspond to the analysis of the cumulative division events, until 96 hours.

Figure 8: Frequencies of HUVEC mother cells able to form 2 HUVEC daughter cells, called "cell division" events. The results shown were obtained by averaging the data of 4 experiments for the irradiated conditions at $40 \mathrm{kVp}$ and $4 \mathrm{MV}$ (blue and black curves, respectively),after $5 \mathrm{~Gy}$ of irradiation and correspond to the analysis of the division events, during 6-hour periods, over 96 hours after exposure.

Figure 9: Mortality frequencies ( \pm S.E.) of HUVECs. The results shown were obtained by averaging the data of 4 experiments for the irradiated conditions at $40 \mathrm{kVp}$ and $4 \mathrm{MVp}$ (blue and black curves, respectively), after 5 Gy of irradiation and correspond to the analysis of the frequency of mortality, during 6-hour periods, over 96 hours after exposure. 
Tables:

Table 1: Irradiation and dosimetry specifications for $40 \mathrm{kVp}, 220 \mathrm{kVp}$ and $4 \mathrm{MVp}$ irradiations

Table 2: Dose response of the mean number ( \pm S.E.) of $\gamma$-H2A.X IRIF per nucleus measured in G0/G1 primary HUVECs, 30 min after irradiation at $0.25,0.5,1$ and 2 Gy. The measured values are given for $40 \mathrm{kVp}, 220 \mathrm{kVp}$ and $4 \mathrm{MVp}$ X-rays. Mean numbers $\gamma$-H2A.X IRIF per nucleus were evaluated with image analysis software on around 4200 cells for each dose, and obtained from at least 3 experiments. Significance was tested using Student's t test.

Table 3: Frequencies of cells with micronuclei and/or nucleoplasmic bridges in G0/G1 cells, $48 \mathrm{~h}$ after exposure to $5 \mathrm{~Gy}$. Values represent means and S.E. calculated from at least 4 experiments (around 4100 cells per condition). Significant differences were tested with Student's t test. 
Bibliography

van Attikum H, Gasser SM. 2009. Crosstalk between histone modifications during the DNA damage response. Trends Cell Biol. 19:207-217.

Beyreuther E, Lessmann E, Pawelke J, Pieck S. 2009. DNA double-strand break signalling: $\mathrm{X}$-ray energy dependence of residual co-localised foci of gamma-H2AX and 53BP1. Int $\mathrm{J}$ Radiat Biol [Internet]. 85:1042-50. Available from:

http://www.ncbi.nlm.nih.gov/pubmed/19895281

Brenner DJ, Amols HI. 1989. Enhanced risk from low-energy screen--film mammography X rays. $\mathrm{Br} \mathrm{J}$ Radiol [Internet]. 62:910-4. Available from:

http://www.ncbi.nlm.nih.gov/pubmed/2819359

Burma S, Chen BP, Murphy M, Kurimasa A, Chen DJ. 2001. ATM Phosphorylates Histone H2AX in Response to DNA Double-strand Breaks. J Biol Chem. 276:42462-42467.

Goodhead DT. 1988. Spatial and Temporal Distribution of Energy. Health Phys [Internet]. 55:231-240. Available from: https://insights.ovid.com/crossref?an=00004032-19880800000015

Goodhead DT, Nikjoo H. 1990. Current Status of Ultrasoft X Rays and Track Structure Analysis as Tools for Testing and Developing Biophysical Models of Radiation Action. Radiat Prot Dosimetry [Internet]. 31:343-350. Available from: https://academic.oup.com/rpd/article-lookup/doi/10.1093/oxfordjournals.rpd.a080694

Gruel G, Villagrasa C, Voisin P, Clairand I, Benderitter M, Bottollier-Depois J-F, Barquinero JF. 2016. Cell to Cell Variability of Radiation-Induced Foci: Relation between Observed Damage and Energy Deposition. PLoS One [Internet]. 11:e0145786. Available from: http://www.ncbi.nlm.nih.gov/pubmed/26727594

ICRP. 2007. ICRP publication 103: Recommandations 2007 de la Commission internationale de protection radiologique. [place unknown].

Kegel P, Riballo E, Kühne M, Jeggo PA, Löbrich M. 2007. X-irradiation of cells on glass slides has a dose doubling impact. DNA Repair (Amst) [Internet]. 6:1692-1697. Available from: http://linkinghub.elsevier.com/retrieve/pii/S1568786407002133

Kellerer AM. 2002. Electron spectra and the RBE of X rays. Radiat Res. 158:13-22.

Kinner A, Wu W, Staudt C, Iliakis G. 2008. Gamma-H2AX in recognition and signaling of DNA double-strand breaks in the context of chromatin. Nucleic Acids Res [Internet]. 36:5678-94. Available from: http://www.ncbi.nlm.nih.gov/pubmed/18772227

Lehnert A, Dörr W, Lessmann E, Pawelke J. 2008. RBE of $10 \mathrm{kV}$ X rays determined for the human mammary epithelial cell line MCF-12A. Radiat Res [Internet]. 169:330-6. Available from: http://www.ncbi.nlm.nih.gov/pubmed/18302480

Lehnert A, Lessmann E, Pawelke J, Dörr W. 2006. RBE of $25 \mathrm{kV}$ X-rays for the survival and induction of micronuclei in the human mammary epithelial cell line MCF-12A. Radiat Environ Biophys [Internet]. 45:253-60. Available from:

http://link.springer.com/10.1007/s00411-006-0062-3 
Lisby M, Rothstein R. 2009. Choreography of recombination proteins during the DNA damage response. DNA Repair (Amst). 8:1068-1076.

Mestres M, Benkhaled L, Caballín MR, Barrios L, Ribas M, Barquinero J-F. 2011. Induction of incomplete and complex chromosome aberrations by $30 \mathrm{kVp}$ X rays. Radiat Res. 175:201207.

Mestres M, Caballín MR, Barrios L, Ribas M, Barquinero JF. 2008. RBE of X rays of different energies: a cytogenetic evaluation by FISH. Radiat Res. 170:93-100.

Panteleeva A, Słonina D, Brankovic K, Spekl K, Pawelke J, Hoinkis C, Dörr W. 2003. Clonogenic survival of human keratinocytes and rodent fibroblasts after irradiation with 25 kV x-rays. Radiat Environ Biophys. 42:95-100.

Paull TT, Rogakou EP, Yamazaki V, Kirchgessner CU, Gellert M, Bonner WM. 2000. A critical role for histone $\mathrm{H} 2 \mathrm{AX}$ in recruitment of repair factors to nuclear foci after DNA damage. Curr Biol. 10:886-895.

Poludniowski G, Landry G, DeBlois F, Evans PM, Verhaegen F. 2009. SpekCalc : a program to calculate photon spectra from tungsten anode x-ray tubes. Phys Med Biol [Internet].

54:N433-N438. Available from: http://stacks.iop.org/0031-

9155/54/i=19/a=N01?key=crossref.8ebd6d2bcf93ed5bcaf5586b 1de91dfc

Dos Santos M, Paget V, Ben Kacem M, Trompier F, Benadjaoud M, François A, Guipaud O, Benderitter M, Milliat F. 2018. Importance of dosimetry protocol for cell irradiation on a low $\mathrm{X}$-rays facility and consequences for the biological response. Int J Radiat Biol [Internet]. 0:129. Available from: http://dx.doi.org/10.1080/09553002.2018.1466205

Schmid E, Regulla D, Kramer H-M, Harder D. 2002. The effect of 29 kV X rays on the dose response of chromosome aberrations in human lymphocytes. Radiat Res [Internet]. 158:7717. Available from: http://www.ncbi.nlm.nih.gov/pubmed/12452780

Sheikh-Bagheri D, Rogers DWO. 2002. Monte Carlo calculation of nine megavoltage photon beam spectra using the BEAM code. Med Phys [Internet]. 29:391-402. Available from:

http://doi.wiley.com/10.1118/1.1445413

Slonina D, Spekl K, Panteleeva A, Brankovic K, Hoinkis C, Dorr W. 2003. Induction of micronuclei in human fibroblasts and keratinocytes by $25 \mathrm{kV}$ x-rays. Radiat Environ Biophys. 42:55-61.

Vaurijoux A, Voisin P, Freneau A, Barquinero JF, Gruel G. 2017. Transmission of persistent ionizing radiation-induced foci through cell division in human primary cells. Mutat Res Fundam Mol Mech Mutagen [Internet]. 797-799:15-25. Available from:

http://dx.doi.org/10.1016/j.mrfmmm.2017.03.003 


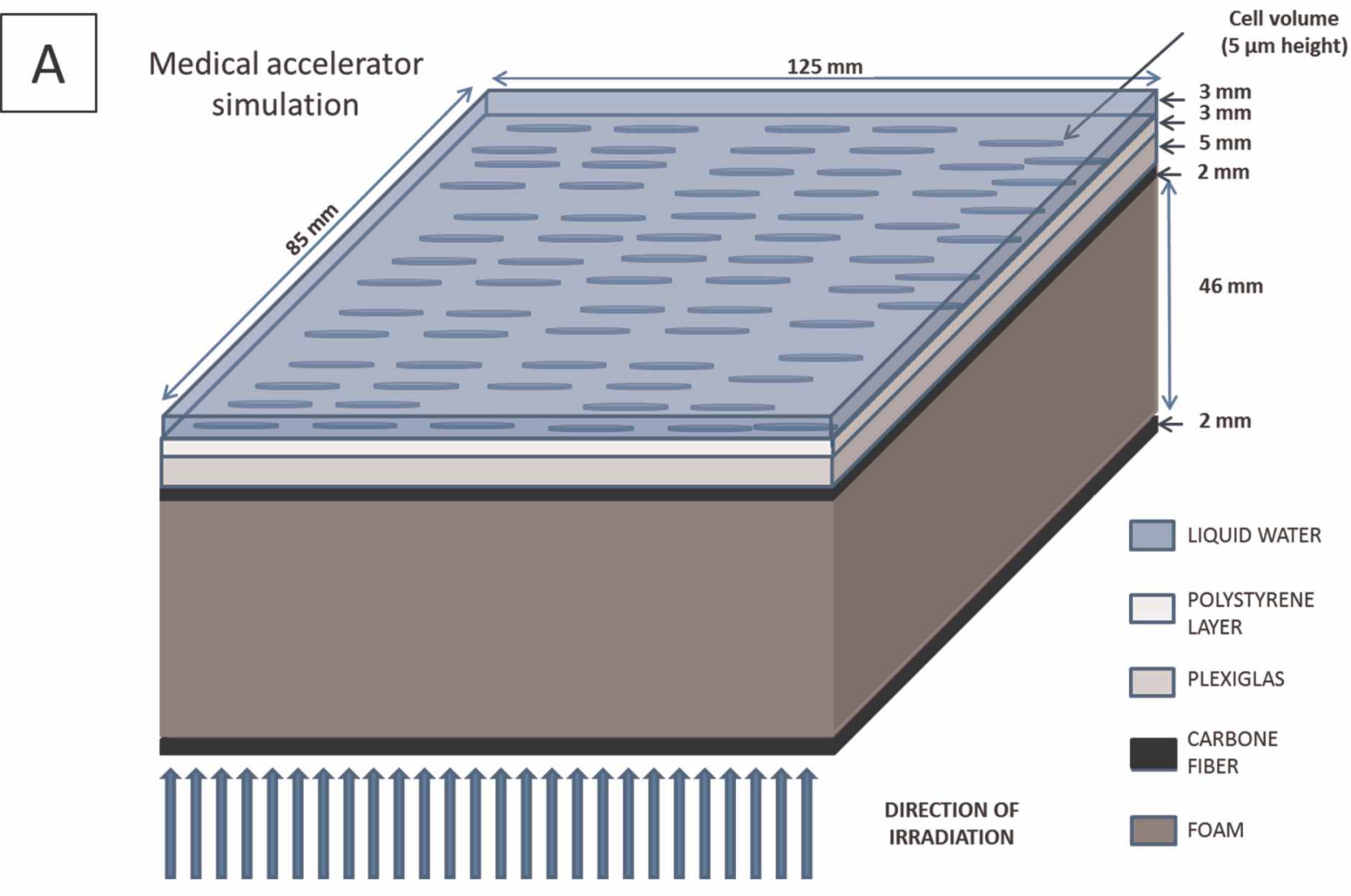

B

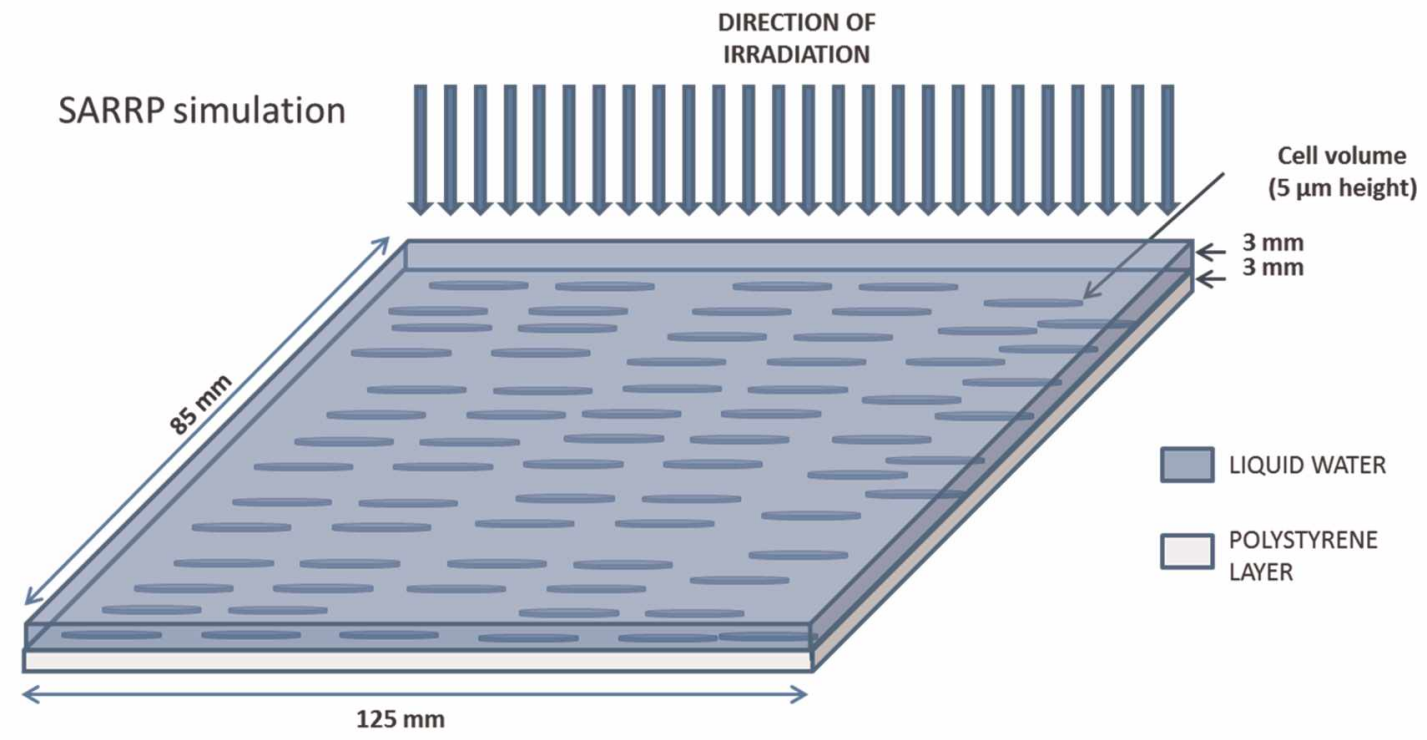




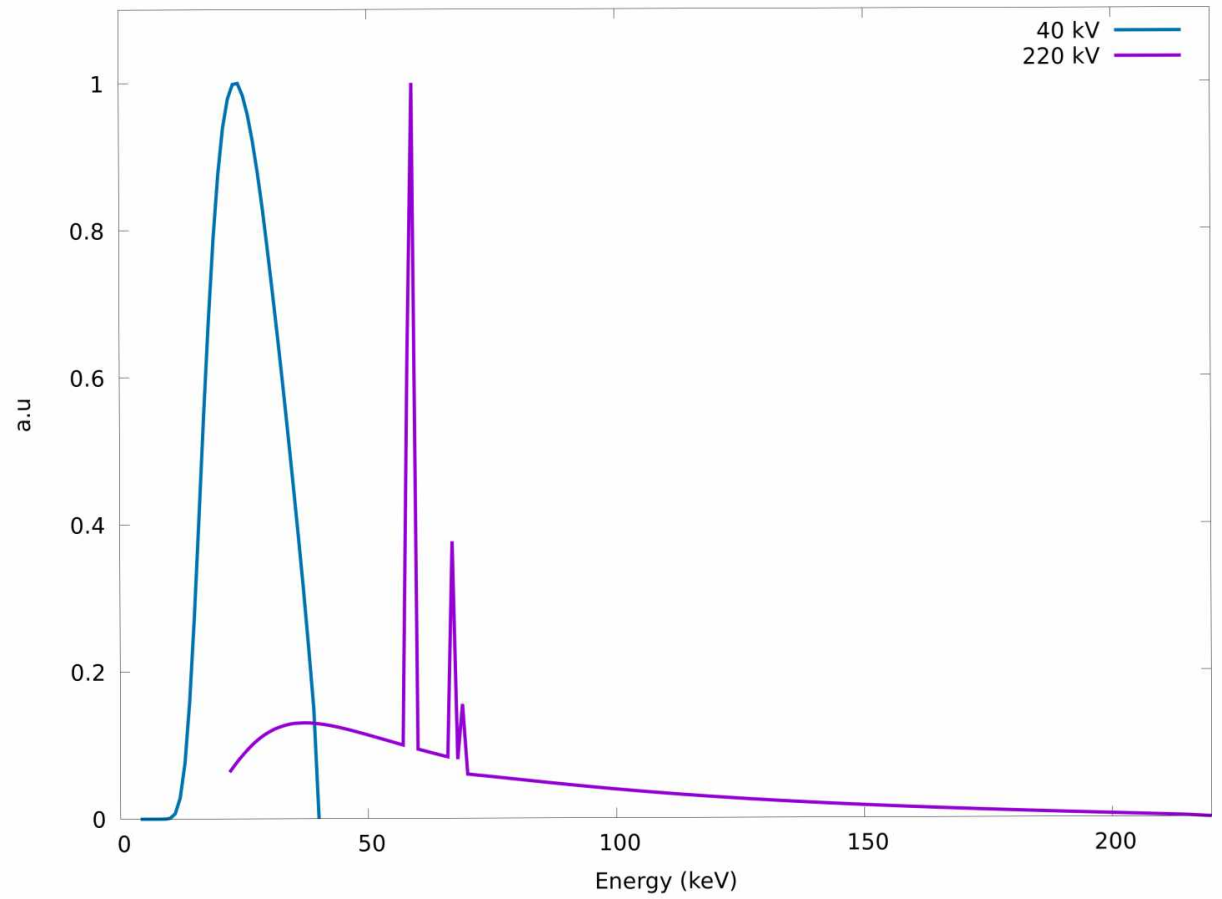




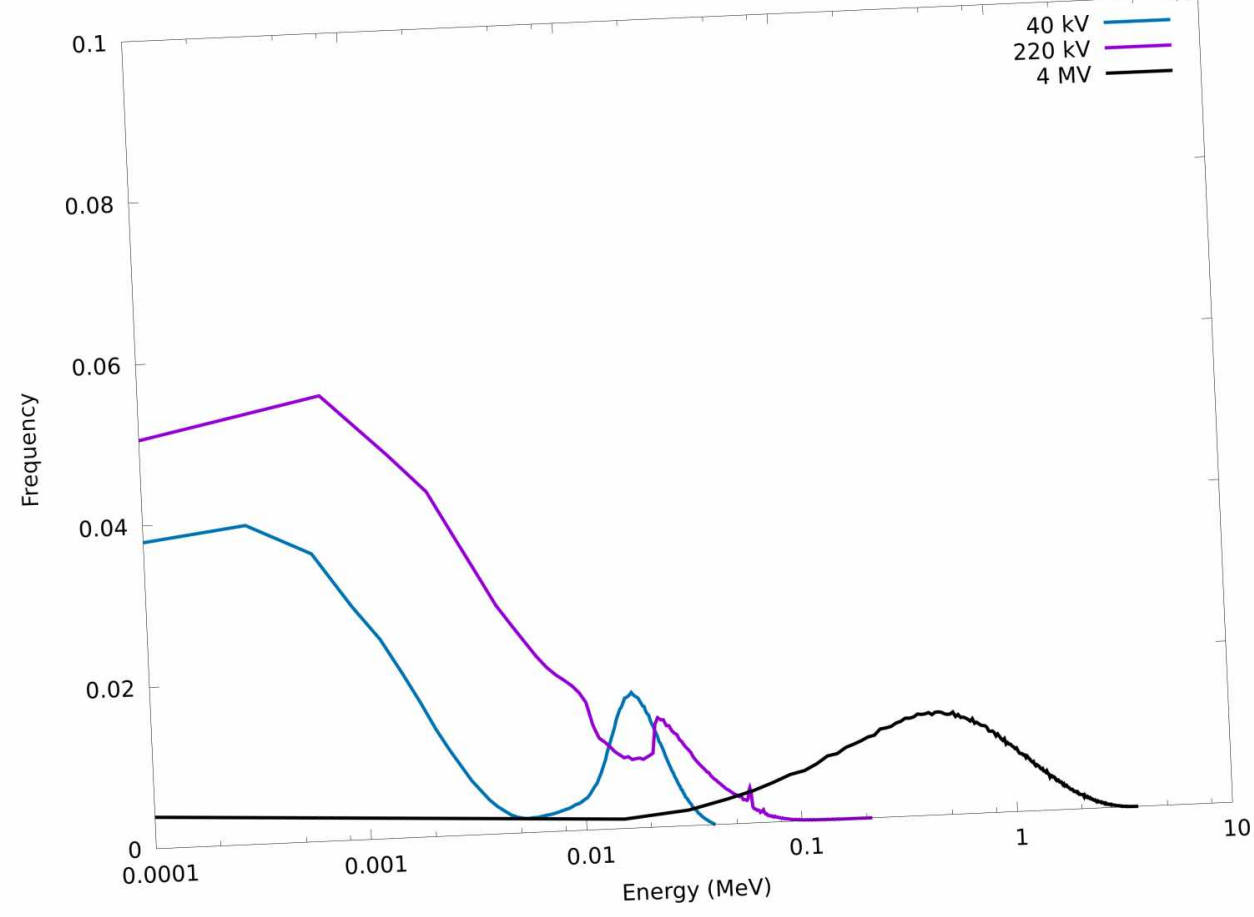




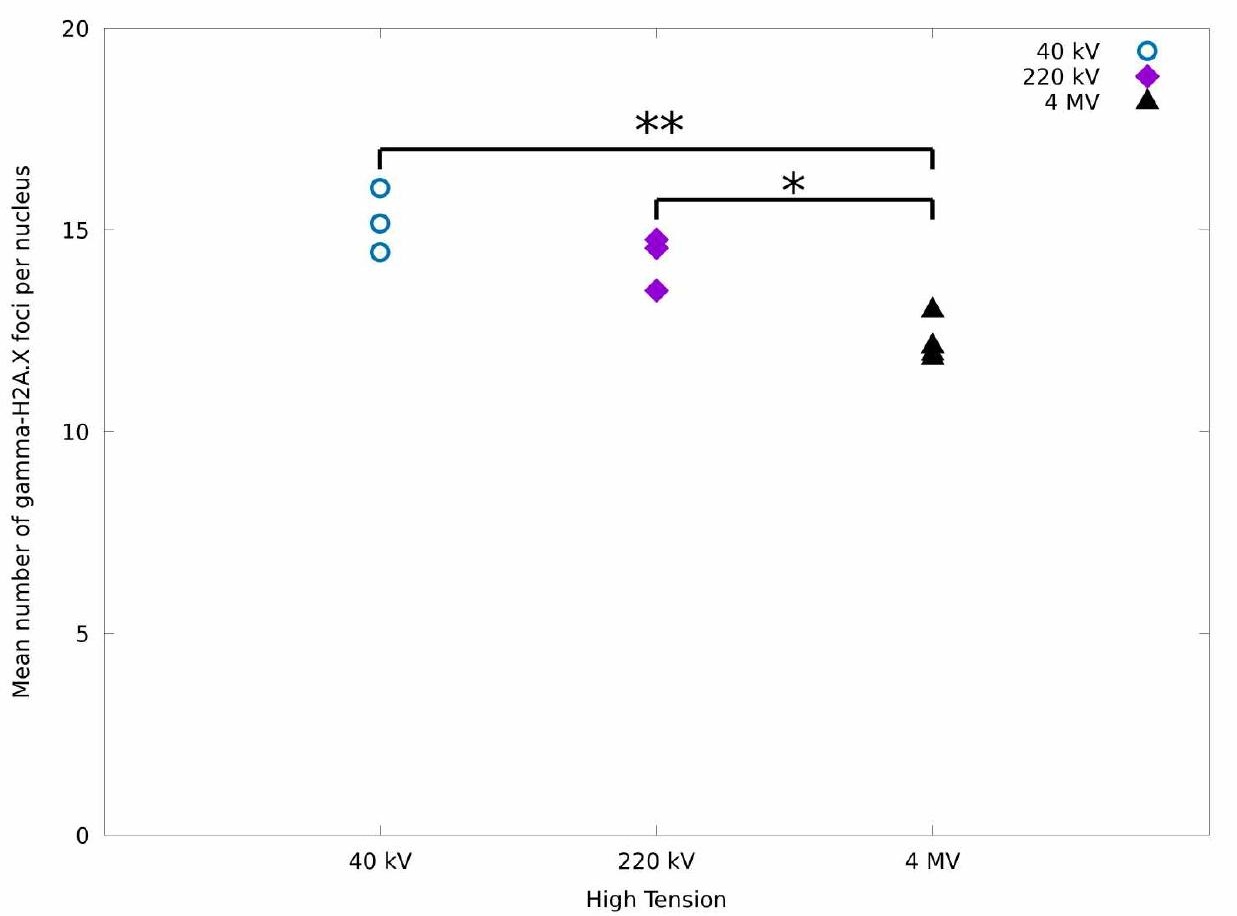




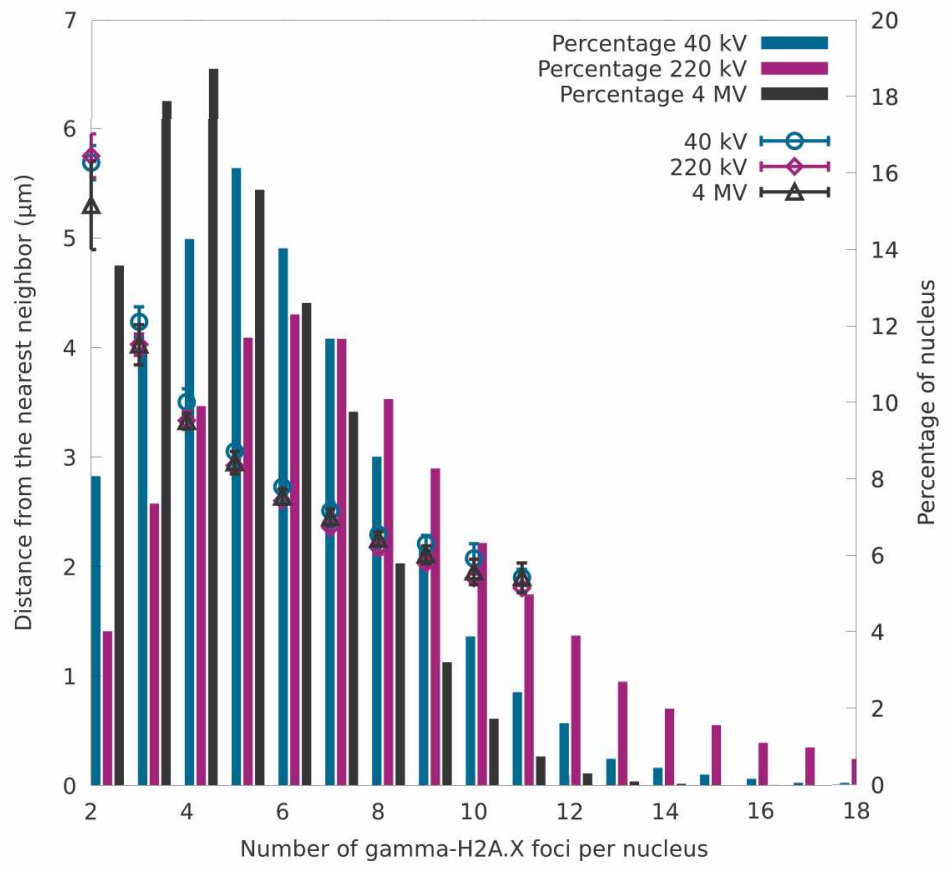




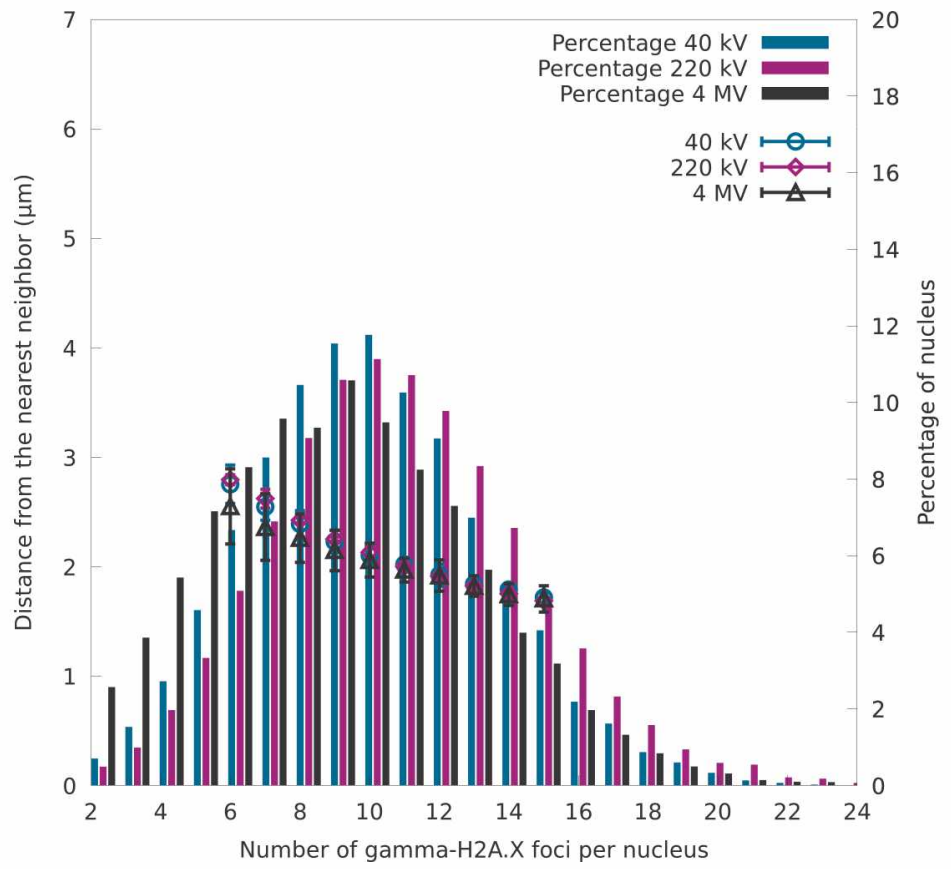




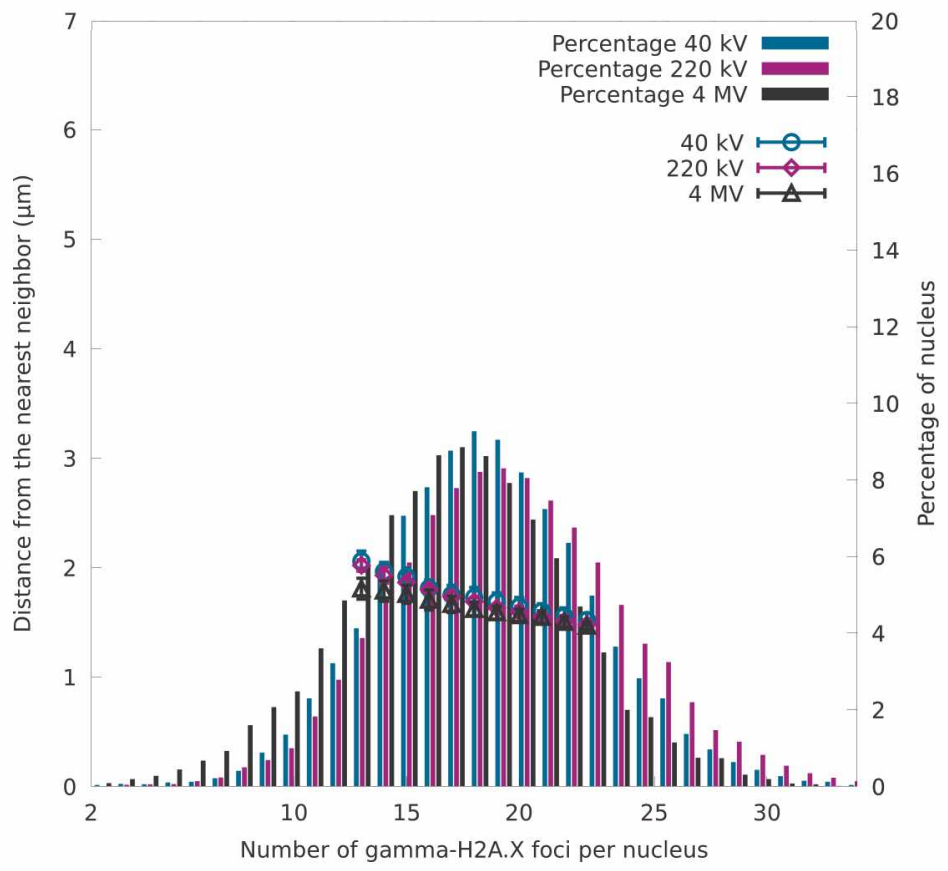




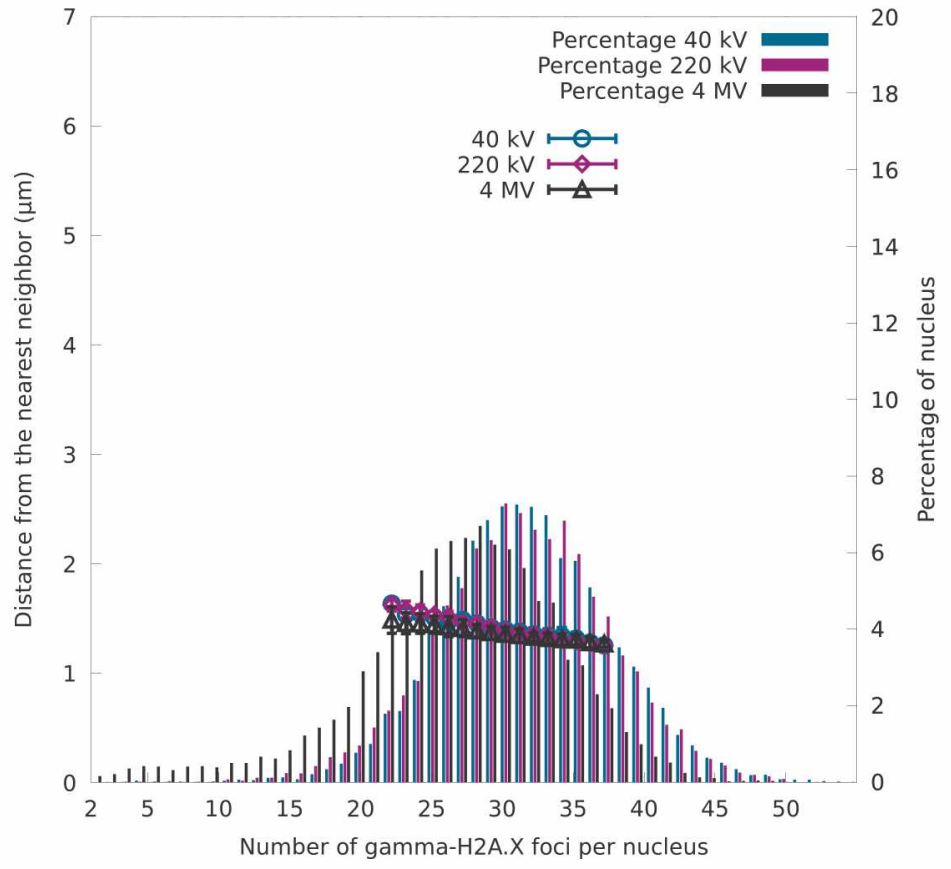




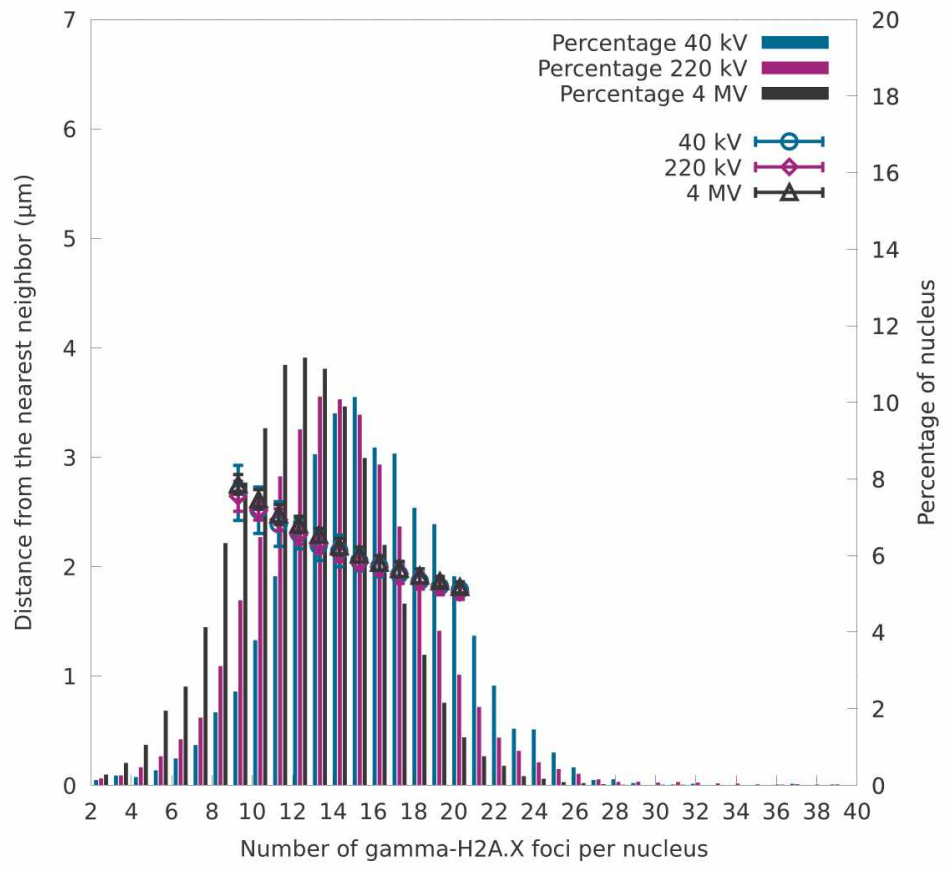




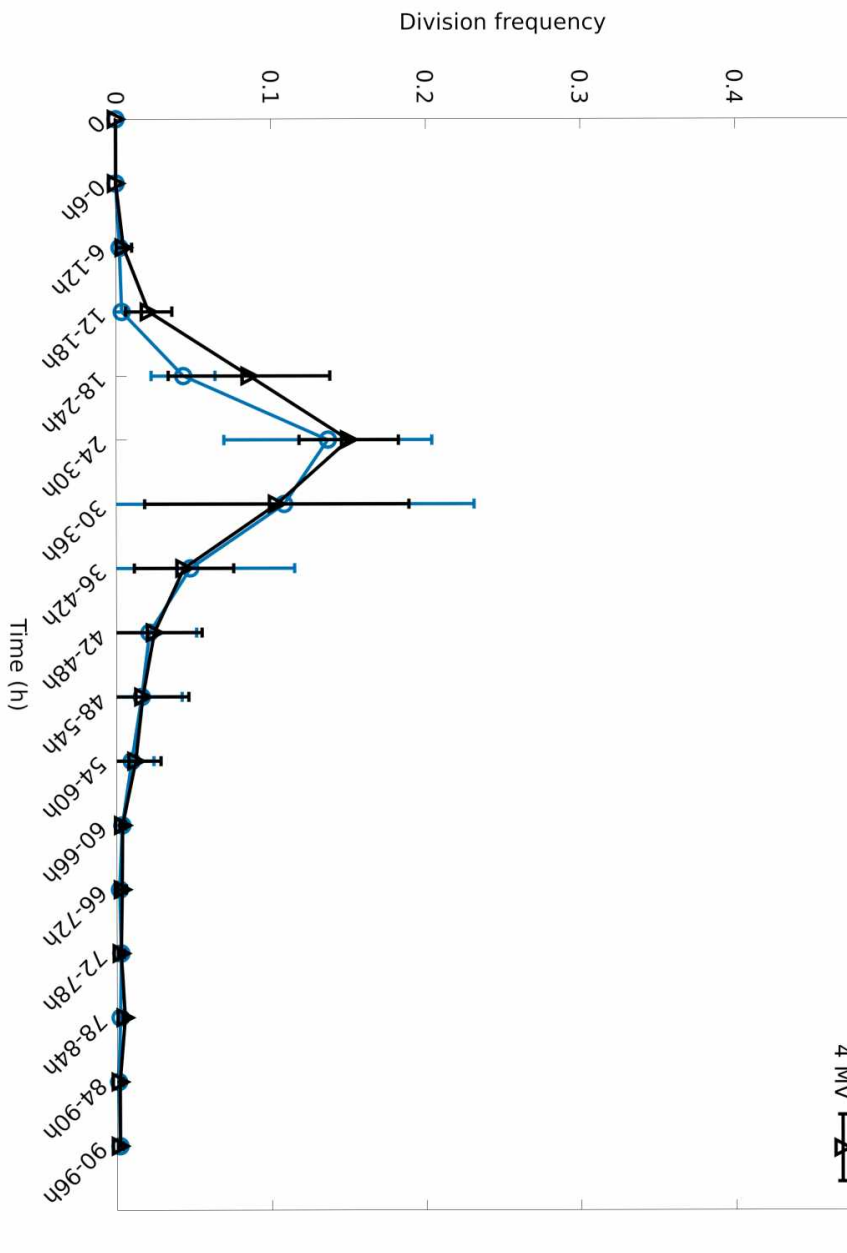




\section{Mortality frequency}

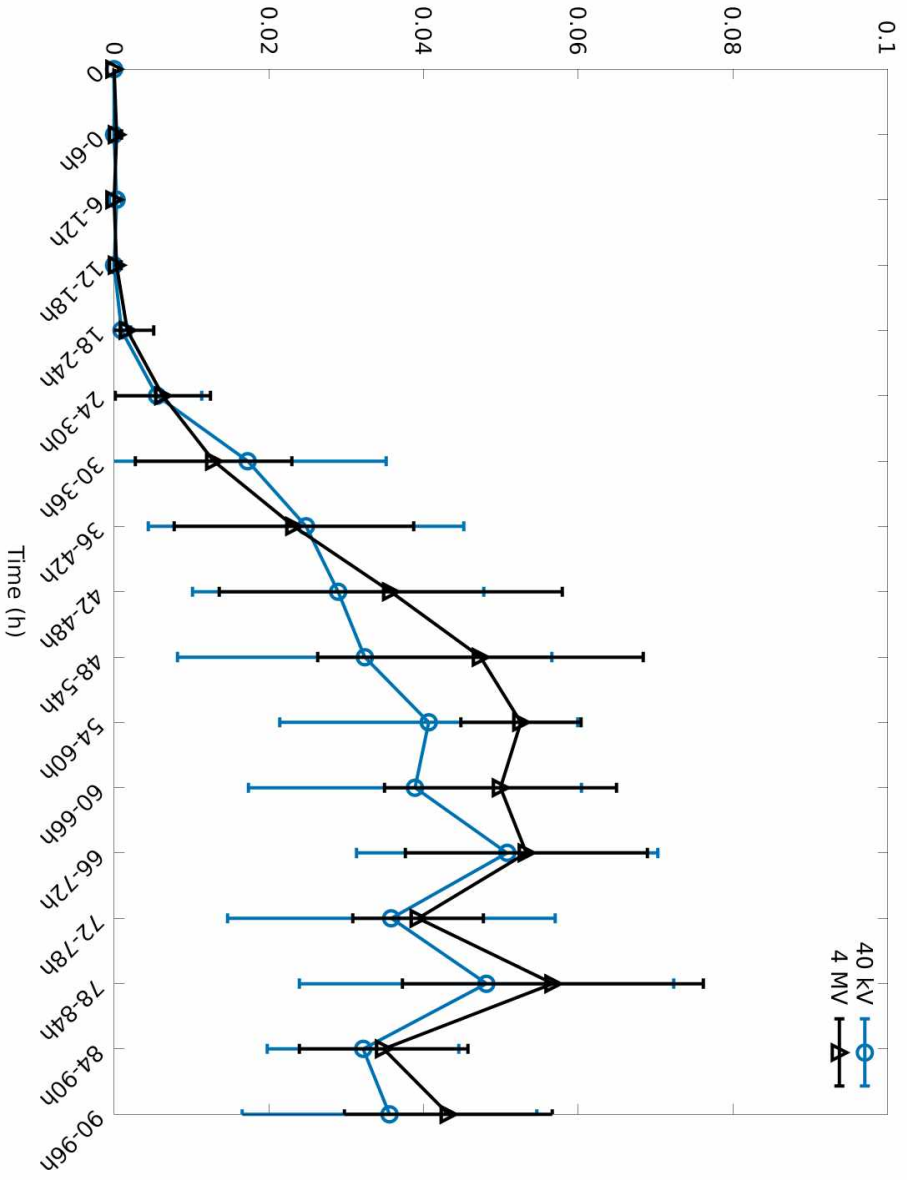




\begin{tabular}{|c|c|c|c|}
\hline $\begin{array}{c}\text { High voltage } \\
\text { Intensity } \\
\text { (mA) }\end{array}$ & $40 \mathrm{kVp}$ & $220 \mathrm{kVp}$ & $4 \mathrm{MVp}$ \\
\hline Filtration & $0.8 \mathrm{~mm}$ of Be $+1 \mathrm{~mm}$ of Al & $0.8 \mathrm{~mm}$ of Be $+1 \mathrm{~mm}$ of Al & \\
\hline HVL value & $0.852 \mathrm{~mm}$ of aluminum & $0.667 \mathrm{~mm}$ of copper & - \\
\hline Irradiation field (cm $\left.{ }^{2}\right)$ & $8 \times 8 \mathrm{~cm}^{2}$ & $8 \times 8 \mathrm{~cm} \mathrm{~cm}^{2}$ \\
\hline Source sample distance \\
(cm)
\end{tabular}

Table 1: Irradiation and dosimetry specifications for $40 \mathrm{kVp}, 220 \mathrm{kVp}$ and $4 \mathrm{MVp}$ irradiations 


\begin{tabular}{|c|c|c|c|}
\hline & $40 \mathrm{kVp}$ & $220 \mathrm{kVp}$ & $4 \mathrm{MVp}$ \\
\hline $0.25 \mathrm{~Gy}$ & $5.35 \pm 1.13$ & $7.35 \pm 2.17$ & $4.35 \pm 0.21$ \\
\hline $0.5 \mathrm{~Gy}$ & $9.88 \pm 0.87$ & $10.24 \pm 1.73$ & $8.54 \pm 1.42$ \\
\hline $1 \mathrm{~Gy}$ & $18.59 \pm 0.43$ & $18.64 \pm 2.33$ & $16.46 \pm 1.63$ \\
\hline 2 Gy & $30.30 \pm 2.21$ & $30.59 \pm 2.96$ & $26.42 \pm 0.87$ \\
\hline
\end{tabular}

Table 2: Dose response of the mean number ( \pm S.E.) of $\gamma$-H2A.X IRIF per nucleus measured in G0/G1 primary HUVECs, 30 min after irradiation at $0.25,0.5,1$ and $2 \mathrm{~Gy}$. The measured values are given for $40 \mathrm{kVp}, 220 \mathrm{kVp}$ and $4 \mathrm{MVp}$ X-rays. Mean numbers $\gamma$-H2A.X IRIF per nucleus were evaluated with image analysis software on around 4200 cells for each dose, and obtained from at least 3 experiments. Significance was tested using Student's t test. 


\begin{tabular}{|l|l|}
\hline Radiation quality & All cells \\
\hline Control & $1.69 \% \pm 1.03 \%$ \\
\hline $40 \mathrm{kVp}$ & $8.68 \% \pm 3.82 \%$ \\
\hline $4 \mathrm{MVp}$ & $11.78 \% \pm 4.40 \%$ \\
\hline
\end{tabular}

Table 3: Frequencies of cells with micronuclei and or nucleoplasmic bridges in $\mathrm{G} 0 / \mathrm{G} 1$ cells, $18 \mathrm{~h}$ after exposure to $5 \mathrm{~Gy}$. Values represent means and S.E. calculated from at least 4 experiments (around 4100 cells per condition). Significant differences were tested with Student's t test. 